\title{
The debates of methodology and methods: reflections on the development of the study of international relations
}

\author{
Amira Abou Samra \\ Department of Political Science, Faculty of Economics and Political Science, \\ Cairo University, Giza, Egypt
}

Received 4 June 2020 Revised 12 August 2020 Accepted 18February 2021

\begin{abstract}
Purpose - This paper aims to explore the interplay between methods and methodologies in the field of international relations (IR) over the 100 years of its lifetime reflecting on the relationship between the rise of new research methods and the rise of new methodologies.

Design/methodology/approach - This paper looks in retrospect into the field's great debates using a historiography approach. It maps chronologically the interplay of methods and methodology throughout the stages of the development of the study of IR.

Findings - This paper argues that inspite of narratives of triumph being common in the field, the coexistence of competing research methods and methodologies is the defining feature of the field. All theories, all methods and all methodologies have undergone a process of criticism, self-criticism and change. New methodologies have not necessarily accompanied the rise of new research methods in the field.

Originality/value - Drawing a map of the field's methodologies and methods reveals necessarily its dynamism and its plurality. An honest map of the field is one that highlights not only theoretical differences but also ontological, epistemological and methodological differences embedded in the field's debates.
\end{abstract}

Keywords Research methods, Metatheory, Methodology, Historiography, Post-positivism

Paper type Research paper

\section{Introduction}

International relations (IR) theorists, especially since the second half of the 20th century, had been inclined to consider concerns over ontology, epistemology and methodology to fall outside the scope of their interest, to be of concern to the field of philosophy (Hay, 2006). Today, however, as IR theory is witnessing its "fourth debate," quite frequently described as a "metatheoretical debate," these concerns are no longer dismissible. There is a growing awareness that discussions over methodology have been marginalized in favour of discussions over theories and that this is something that needs to be remedied (Chernoff, 2007, p. 2).

(C) Amira Abou Samra. Published in Review of Economics and Political Science. Published by Emerald Publishing Limited. This article is published under the Creative Commons Attribution (CC BY 4.0) licence. Anyone may reproduce, distribute, translate and create derivative works of this article (for both commercial and non-commercial purposes), subject to full attribution to the original publication and authors. The full terms of this licence maybe seen at http://creativecommons.org/licences/by/4.0/ legalcode

The study of international relations 
This paper argues that learning about the theoretical assumptions, without paying due attention to methodological and methodical aspects behind them, leaves researchers halfway through, either blinded to the plethora of possible alternative ways available to deal with political reality or rather totally unequipped to deal with it. Whilst highlighting the methodological and methodical debates that have been going on in the field, this paper argues that telling the history of the relationship between research methods and methodology is an important alternative way of telling the story of the field debates, leading to the appreciation of deeper differences and similarities between its paradigms and theories and to the answering of important questions about methodological plurality in the field, the meaning of science and future concerns for the study of IR.

Hence, the paper is not concerned with the great debates of the field as such, but rather interested in drawing a historiographical map of field debates in a way that specifically addresses the interplay between methodology and methods, seeking, thereby, to answer a number of questions: If it is common to highlight changes in the research methods of the field by referring to two basic tracks, the traditionalist-behaviouralist-post-behaviouralist track and the positivist, post-positivist track (Mostafa, 2016, pp. 57-70; Mosafa, 2010, pp. 840-846), where do methodologies diverge and converge in these two tracks? What is the relationship between the emergence of new research methods and the emergence of new methodologies in IR? How does literature in the late 1980s exploring a methodological turn in IR (Little, 1991, pp. 463-478) differ from literature in 2017 lamenting over an overdue methodological turn (Kanfo, 2017)? Do new research methods and new methodologies coexist with old ones? Do they necessarily compete? If methodology is the process of establishing scientific inquiry (Kaplan, 1964, pp. 22-24), what impact does the existence of multiple methodologies have on the meaning of science?

For conceptual clarity, methodology and research methods fit into a matrix of interconnected and interrelated concepts as broad as epistemology, ontology, methodology and theory. In philosophical traditions, "ontology" corresponds to the study of being or existence, where the answers to major questions about the relationship between human beings, the universe and nature are reflected upon. The ontology generates a specific view of knowledge, that is, the epistemology. Epistemology answers questions such as: What can we know and what are the sources of knowledge? What is the purpose of knowledge? Is "certain" knowledge ever achievable? Is the development of knowledge and science progressive in nature so that newer theories necessarily carry more knowledge than older ones? The epistemology provides the background foundation for all theorization. Directly derivable from the epistemology are both the ontology of the field and its methodology (Abul-Fadl, 1994; Krauss, 2005).

It is important to distinguish between the philosophical understanding of ontology, where ontology as a theory of existence serves as a driver of epistemology, a theory of knowledge and methodology as a process of producing science on the one hand, and between ontology in the understanding of the field of IR, where the word "ontology," though borrowed from philosophy, stands for the content of political reality in the field, e.g. "identities, individuals, social collectivities, states, regimes, systems, or some combination of the above." (Hay, 2006). Ontology in social sciences answers also the question of "what is reality," hence, whether reality has a solid and an independent existence from researchers or whether reality is just "fluid and constructed the result of human perception and claims about it" (Lacatus et al., 2015).

Methodology is defined by Abraham Kaplan (1964, pp. 22-24) as "the logic of scientific research"; the process by which science is produced. Kaplan's definition of methodology is broader, even more neutral, than definitions that, later on, directly link methodology to 
empiricism, whereby empiricism is a methodology used to "form theoretical claims and to test their empirical implications." In such a narrow definition of methodology only what is empirically testable, hypotheses that can lend themselves to falsification by being subjected to a test of reality, is science (Sprinz and Wolinsky-Nahmias, 2004, p. 4). This definition of methodology is inseparable from a definition of theory that regards theory as a set of assumptions to be tested against reality for accuracy, validity and quality (Sprinz and Wolinsky-Nahmias, 2004, p. 4).

In its broad definition, however, methodology refers to a process that produces science. Even if that science is not testable against reality; for so many reasons, amongst which might be the belief that there is no neutral or independent existence of reality that it can be tested against to begin with, as will be furtherly explained throughout the paper.

Ultimately, what one considers as "science" and what one accepts as "theory" are products of what one believes in, epistemologically, ontologically and, by consequence, methodologically.

Methodology produces theories that end up producing or making use of approaches or research methods which answer the question: What are the specific steps that the researcher must follow to get to answer his research question?

This paper is divided into two main parts looking in retrospect into the debates of the field, chronologically mapping the interplay of methods and methodology through the stages of the development of the study of IR. The first part, divided into three sections, tells the story of the development of the study of IR over a time span of around 60 years until the end of the 1970s or mid-1980s which mark the beginning of the "relative" demise of the behaviouralist "hegemony" over the field.

The second part of the paper, divided into three sections, covers the period starting from the relative "demise of the empiricist positivist promise for a cumulative positivist science" in the late-1970s and mid-1980s until our present time (Little, 1991, p. 463), asking whether the past four decades have brought along some methodological turn in IR or simply a shift in research methods and techniques.

\section{Part I: traditionalism-behaviouralism-post-behaviouralism \\ Traditionalism vs. behaviouralism: from the science of advice to the science of grand theories}

The positivist enlightenment project though produced in Europe, flourished and boomed in the USA. Positivism was and still is a dominant feature of the American understanding of social reality (Smith, 2000, p. 375). Behaviouralism as a positivist methodological approach to the study of political science had its origins in the USA in the 1920s and 1930s and has been usually associated with the University of Chicago and the works of Charles Merriam (Grigsby, 2011, p. 15). Behaviouralism was influenced by behaviourism (Hafner-Burton et al., 2017, pp. S1-S3), a school of psychology reflecting positivism, a "belief in the infinite possibilities of science" and "in the powers of the human mind," where logic and reason constitute the only source of all certain knowledge (Herakovic, 1983, p. 10). In behaviourism, human behaviour can be simplified to the extent that it can be measured in the here and now without any reference to past experiences or inner motives (Herakovic, 1983, pp. 70-82). Human behaviour can be observed, monitored and interpreted based on its external features (Hamati-Ataya, 2012, pp. 3-4). Behaviourist assumptions were influenced by the "stimulus and response idiom", and were, hence, advocating that living organisms - be they animals or human beings - interact with all forms of external stimuli in a manner that seems to be quite uniform. Behaviouralism was furtherly influenced by the behaviourist belief that "the same laws that governed the physical world could be applied to human nature," hence came
The study of international relations 
the appreciation for controlled laboratory experiments and empiricism, where the senses are the main sources of knowledge. Although behaviouralism later on distinguished itself from behaviourism (Hamati-Ataya, 2012, pp. 3-4), behaviourism's impact on social sciences in general and political science in particular could not be mistaken. Behaviourism had already been influential in other social sciences since the past decades of the 19th century (Davis, 1965; Smith, 1989). There, "tough minded empiricism overthrew the hegemony of the moral philosophy of the seventeenth and eighteenth centuries" and carried along an "epistemic transformation" to social sciences (Davis, 1965; Smith, 1989) replacing "absolute sources of truth" with the "boundless belief in the powers of the human mind" (Herakovic, 1983, p. 10). This is why the behaviouralist turn in IR was not just a methodological turn, but rather mainly an epistemic turn.

In the field of IR, behaviouralists in the 1950s were propagating to be the missionaries of a "scientific revolution," endorsing the following set of basic assumptions:

First, IR as an independent social science: Behaviouralism advocates the ability of IR to exist as an independent social science. That advocation stands in deep contrast to a traditional perception of IR as a common/joint research area shared by many fields and sciences - such as philosophy, law, economics and even political science (Finnegan, 1972, p. 40). Interestingly, behaviouralism borrowed approaches from other fields such as mathematics, physics, biology, economics, sociology and psychology, hence not only from natural sciences but also form social sciences that were already witnessing a behaviourist turn, fields that traditionalism did not consider as relevant to political science though (Hamati-Ataya, 2012, p. 5).

Second, the unity of scientific knowledge: behaviouralists considered IR (as a social science) to be quite similar to the natural sciences, where description, measurement, observation and quantitative, mathematical and statistical tools were essential research tools. Traditionalists rather considered IR to be closer to humanities, closer to literature and philosophy, where analysis and contemplation were key to understanding international reality.

Third, science is value-free: In contrast to the traditional perception in which values are inseparable from science and where, therefore, history, political theory and law are indispensable to the understanding of the international phenomenon (Chernoff, 2007, p. 2); behaviouralism promoted the possibility of establishing an objective, value-free science in which researchers play a completely neutral role. The reproducibility of knowledge is a key behaviouralist assumption; just by following the same steps, researchers anywhere can get almost the same results (El-Hayagna, 2001, p. 111).

Fourth, the possibility of producing major and general theories in IR: A good theory in traditionalism is to be tested against history, political theory and law (Chernoff, 2007, p. 2). Behaviouralism claims a good theory is a simple theory that depicts as "less complex causal mechanisms" as possible. Hence, it relies on measurable variables for explaining, even predicting phenomena under study (El-Hayagna, 2001, pp. 83-89).

The behaviouralist-traditionalist divide is much more than a divide over research methods; it is a divide over the appropriate methodology for producing "science," with some clear epistemological and ontological aspects of divergence that will be furtherly discussed in the following section.

Rise of behaviouralism: a journey not void of criticism

Traditional approaches to thinking about political reality were quite prevalent in political science in the early 20th century (Druckman et al., 2006, p. 627). 
The early beginnings of the field in the aftermath of the First World War seemed strongly influenced by the ideas of idealists. The likes of the idealist Wilson were driven by a desire to "guide the conduct of states in their IR (towards a more peaceful world), rather than focusing on the actual behaviour of states" (Hellman, 2011, p. 18). This explains why the study of IR from an idealist perspective was guided by an interest in political philosophy, international law and diplomacy, the approaches quite familiar to traditionalism (Hellman, 2011, p. 18).

Behaviourialism in the field of IR had many critics along the process of its relative rise Hedley Bull and Stanley Hoffman just to name a few (Hamati-Ataya, 2012, p. 17).

Some criticized the fact that behaviouralist studies overlooked cultural diversity and ignored the richness of human experience (Dyer and Mangasarian, 1989, p. XVII).

Some criticized behaviouralist claims about the existence of value-neutral science, especially given the growing tendency to equate "observation" with "quantification." Although behaviourialism did not completely displace values from scientific research, it limited its study to the empirical manifestations of values. An interest for values in a normative sense was relegated to the realm of political philosophy (Hamati-Ataya, 2012, pp. 7-10).

Growingly, some warned against the dangers of being "attached to spurious statistical and mathematical correlations" drawing, therewith, the attention to the importance of "testing sophisticated statistical methods" for "real correlations, questioning the significance of these correlations in the absence of human judgement to evaluate them" (Forward, 1971, pp. 18-20).

Strikingly, some behaviouralists seemed to struggle with their own behaviouralism. They complained about the lack of data and the confidentiality of many aspects of relations between states. They struggled with the large number of variables affecting IR and with the absence of a clear classification for them. They even complained about cultural and social differences they encountered whilst studying states, a discovery that seemed to impede their pursuit of general laws (Davis, 1965, pp. 15-16).

Obviously behaviouralism was not walking its way of empirical political analysis in the absence of research difficulties or amidst general satisfaction. Behaviourialists - in a way maybe comparable to post-positivists today - complained even about their inability to communicate easily with decision-making circles and to influence them (Forward, 1971, p. 20).

But the criticisms of behaviouralism - from Europe mainly and sometimes from within the USA itself - did not prevent the spread of behaviouralism, even in Europe (HamatiAtaya, 2012, pp. 6-7).

Although behaviouralism - as previously mentioned - was mainly a product of an American social and political context (Hamati-Ataya, 2012, p. 2) and was originally loaded with epistemological, ontological and methodological claims driven from the particularity of positivist enlightenment (Herakovic, 1983, p. 10), the traditional-behaviouralist debate most probably under the influence of the behaviouralist disinterest in philosophy - was usually presented as a debate over appropriate research methods, rather than a debate over the appropriate scientific methodology or the philosophy of science itself. The debate ignored the questions of what constitutes science and whether social sciences have a distinct nature from natural sciences, questions that remained vibrant in the field of philosophy at that time (Little, 1991, p. 468).

Looking in retrospect, however, it makes a lot of sense to talk about behaviouralist methodology, not only behaviouralist methods, although the advocation that
The study of international relations 
behaviouralism is charged with epistemological, ontological and methodological content was not that common during the rounds of traditional-behaviouralist debate.

According to Richard Little (1991), the methodological difference between traditionalists and behaviouralists - though existing since the very beginning - remained unexplored in the field of IR at least until Kenneth Waltz introduced his neo-realist theory in the 1970s (Little, 1991, p. 446). The following section explains this statement. The section revolves around the relationship between behaviouralism and realism on the one hand and behaviouralism and neo-realism on the other hand and how the emergence of neo-realism influenced the methodological and methodic debate taking place in the field of IR.

\section{Behaviouralism and realism: the joint journey}

With the end of the Second World War, the field became more receptive to realist assumptions. To realism, some attribute the credit for shifting the study of IR from the "science of international values and ethics" - that many have lost their faith in as a result of the Second World War experience - to the "science of studying power and interest" (Badran, 2000 , pp. 71-72). This obviously was not only implying an ontological shift, moving away from the study of what ought to be to the study of what really is. It was implying an epistemological shift from transcendental meanings of right and wrong, good and bad to a man-centred definition of interests and morality. Many of the realists advocated the need for a general explanatory theory of IR (Forward, 1971; Davis, 1965; Hamati-Ataya, 2012). Behaviouralism, therefore, was highly compatible with the realist needs, the former allowed for "the pursuance of Realism's scientific aspirations with the emerging methods and techniques of the age" (Hamati-A taya, 2012, p. 12). The realist-behaviouralist partnership set the stage for their mutual rise within the field.

Maybe the relative rise of behaviouralism can be explained by the field's longing for a more predictable international environment that is subjectable to accounts of reason and logic to encounter a dangerous Cold War international environment (Forward, 1971, p. 20) or just a by-product of the American victory in the Second World War; just a triumph of the knowledge preferences of the more powerful; saying nothing about the quality or worth of behaviouralism per se. Anyway, many consider the period after the Second World War to be the period of the "second and serious foundation of the discipline" dedicated to the reconstruction of a US-led world order (Ekkehart Krippendorff, 1987, p. 57). So, and regardless of possible explanations for that, the behaviouralist empirical studies presented themselves from the 1950s onward as the only possessors of a "scientific methodology" in IR (Chernoff, 2007, pp. 79-130). Studies sometimes even still refer to behaviouralism as the "scientific approach" to the study of IR, a label that might misleadingly suggest to the unexperienced reader that only behaviouralism is capable of producing "scientific" knowledge in the field.

Under the behaviouralist-realist collaboration, many research methods/approaches were introduced to the study of IR, amongst the most famous of which are rational choice methods such as the game theory, the decision-making approach in foreign policy, etc., mainly oriented towards the study of great power politics with special emphasis on questions of war and military conflict (Forward, 1971).

Of particular importance is the shift in the thinking about the study of IR brought along by Kenneth Waltz (1979). Waltz, arguably a behaviouralist himself (Dolan, 2014, p. 59), directed serious criticism to behaviouralists.

Waltz' theory revolved around the assumption that anarchy restricts the behaviour of states, forcing them to adopt a conflictual-competitive attitude in a way that reproduces this anarchy over and over and guarantees the continuity of the state system itself. Waltz 
claimed that the global failure to develop a general IR theory is explicable by the failure of IR theorists to understand this methodological background from which all theories and approaches should depart. To Waltz, his neo-realist systems theory was not just a theory, it was the only viable methodology in IR.

Already as early as the 1970s and 1980s, Waltz's theory came under scrutiny, especially with the emergence of neo-liberalism and neo-Marxism. The neoliberal theory criticized Waltz's insistence on ignoring non-competitive forms of relations between states such as those embodied in developments of international law and international institutions (Little, 1991, pp. 463-466). On its part, neo-versions of Marxism mainly criticized the claims of systems theory that political power was distributed almost equally between states, because these claims remained oblivious to power relations between different social groups (Linklater, 1986, pp. 301-312). These criticisms set the stage for what will become known as the neo-realist, neo-liberal, neo-Marxist debate and later on as the inter-paradigm debate (Hoffman, 1989, pp. 60-61), embracing theoretical plurality in the field (Little, 1991, p. 463). Interestingly, some of the most prominent neoliberal and neo-Marxist theories were behaviouralist theories, the neoliberal institutionalism and the neo-Marxist Wallerstein's world-system theory are but examples.

More importantly, in opposition to Waltz's claim of being in possession of the only scientific methodology, some studies in the field of IR began to raise doubts - finally explicitly - about what the philosophy underlying knowledge in the field of IR should be, whether the field had ever actually been comparable to natural sciences with static laws built in the structure of the universe itself, whether IR was not rather similar to humanities (Ferguson and Mansbach, 1988, pp. 656-657). These criticisms were directly targeting the positivist understanding of the world underlying the behaviouralist project and its theoretical advocates - be they neo-realist, neo-liberal or neo-Marxist, reopening, therewith, the way for history, political thought, culture and values to influence the study of IR (Badran, 2000, pp. 69-96).

It is important to note that the failure to explain and predict the end of the Cold War was not the only shortcoming of Waltz's theory. Reality kept surprising neo-realists, whose theory could not later on explain things as major as the continued existence of NATO, inspite of the end of the Cold War (McCalla, 1996, pp. 445-475) or developments in the integration process of the European Union.

Theoretical promises to provide exhaustive answers were not fulfilled even in the case of a theory as popular as Waltz's, declaring, thereby, that realism cannot become a "methodology" for studying IR as Waltz wanted for it to be, but more importantly declaring the "demise of the empiricist positivist promise for a cumulative behavioural(ist) science" (Little, 1991, p. 463).

The accumulated criticism to the behaviouralist scientific project would acquire sometimes the title of "post-behaviouralist revolution" (Hoffman, 1989, p. 60), revolting against some essential behaviouralist assumptions:

Some post-behaviouralist studies criticized the marginalization of history, the history of the West and the history of peoples around the world in a way that impoverished "the content, the perspectives and tools of IR theory” (Ekkehart Krippendorff, 1987, p. 28).

Moreover, some studies criticized the marginalization of normative theorizing in IR, the deliberate neglection of nonmaterial aspects of international politics. For example, the English school would direct serious criticism to the absence of "normative inquiry into the relationship between order and justice," and social constructivism would complain about the negligence of the role of norms in shaping states' identities and interests (Reus-Smit, 2009a, 2009b, p. 66).
The study of international relations 
Worth noting also is how some studies criticised behaviouralist claims of science being value free and produced early attempts at highlighting some relationship between knowledge and interests by criticizing an American hegemony over the field. Some noted that behaviouralist IR theorizing managed to make the behaviour of the USA become a standard and everyone became dedicated to "justify the unique and frightening accumulation of power in conjunction with the world mission of the United States of America," rather than challenge or even criticize it (Ekkehart Krippendorff, 1987, p. 28).

Post-behaviouralist criticisms to behaviouralism seemed to reiterate many of the traditionalist concerns about the utility and quality of behaviouralist theorizing in IR. However, advocating these criticisms were now several separate theories that began to emerge throughout the late 1970s, 1980s and 1990s: the English school, the postmodern theory, the social constructivist theory, the feminist theory, etc. These theories would gradually line up in the face of the three theories of the inter-paradigm debate. The latter would collectively be called the traditional theories or the mainstream theories of IR (Sprinz and Wolinsky-Nahmias, 2004, p. 5). This would leave the field in an unprecedented state of basically ontological and methodic - fluidity far from being able to agree on the core aspects of the international study such as the main actors, the main issues or even the nature of international processes as vital as globalization itself, growingly realizing that the mainstream theories in the field were incapable of catching up with the complexity of reality and its rapidly changing nature (Mostafa, 2016, pp. 70-98).

Criticisms would evolve to produce two different calls in terms of methods and methodology. The first call will defend and retain the positivist character of the field, opening up only to a plurality of research methods, whereas the second call will defend the need for a completely new research attitude towards IR, advocating a post-positivist methodological turn in IR. In the following part, these two calls and the ensuing developments will be tackled in some detail.

\section{Part II: from post-behaviouralism to post-positivism}

Easy way out: a call for reconciliation between research methods

Early responses to criticism to behaviouralist approaches came in the form of calls for "reconciliation" between quantitative - using tools such as statistical analysis, regression coefficients, simple mathematical calculations - and qualitative approaches to international political analysis - using tools such as event analysis, case study, content analysis, interviews, comparisons, etc. (Mahoney and Goertz, 2006, pp. 227-228) (Boassen, 1991, pp. 192-207), acknowledging some of the analytical shortcomings of quantification and accepting a degree of plurality of research methods in the field. Here, shortcomings of behaviouralism were addressed by responses at the level of research methods, rather than the level of methodology.

Obviously, quantitative and qualitative studies were still supposed to "worship the same (positivist) God," where science is all about testable observation, even if they disagreed on smaller goals, qualitative studies producing "cause of effect explanations" and quantitative studies producing "effect of cause explanations" (Mahoney and Goertz, 2006, pp. 227-228).

A similar conclusion was reached by Sprinz and Wolinsky-Nahmias who believed "methodological pluralism" became a necessity (Sprinz and Wolinsky-Nahmias, 2004, pp. 7-8). It is important to note that their reference to methodology is closer in meaning to "approaches or research methods," rather than methodology as a process of scientific inquiry. This is because the advocated plurality of quantitative and qualitative approaches remained a plurality within the confines of an understanding of science as testable observation, embodying the logic of causation. Enough proof is that a one-third of studies 
published in prominent journals were discarded from the analysis of Sprinz and WolinskyNahmia's study - though calling for methodological plurality - because of being "devoid of scientific methodology," i.e. because of being descriptive and historical (Mahoney and Goertz, 2006, p. 8).

Hence, the emergence of qualitative studies as such did not undermine the positivist epistemology and its related methodology in a way that would justify a real methodological distinction between qualitative and quantitative research. It is important not to confuse the positivist qualitative approaches with the post-positivist qualitative approaches to be discussed later on.

Still in the 21st century, admitting the deficiencies of behaviouralism is not an easy task for its advocates. Rather than criticizing the product of empirical behaviouralism, some explained the failure of behaviouralist studies to provide sober political analysis for major events by the failure of behaviouralist studies to grasp the real essence of experimentation, claiming that behaviouralist studies never really conducted an experimental study "in the sense of controlled manipulation as when a single factor is modified, whilst holding everything else constant," what they did was rather closer to non-experimental empirical tests far from satisfying the "modern meaning of experimentation" (Druckman et al., 2006, pp. 628-629). Here, behaviouralist studies failed, because they were not behaviouralist enough.

Yet, although the advocates of behaviouralism are obviously still far away from being disenchanted with it, most of them have become disenchanted with the goal of reaching a general theory in IR. Instead, the goals of experimental research - whatever the definition of experimentation - have become much more modest serving three purposes: searching for facts to "adjucate disputes" in cases in which studies seem to reach contradictory results, to test the accuracy of certain theoretical assumptions and to advise the political leadership (Druckman et al., 2006, pp. 632-633).

So, new was just a degree of humility about the ability to generalize the conclusions of quantitative studies and a degree of humility about the limited ability of quantitative and experimental research to address some specific research areas, such as the study of civil wars, terrorism or regime stability (Druckman et al., 2006, p. 633), all leading to the above highlighted calls for a reconciliation between qualitative and quantitative approaches.

Anyway, according to this view, the traditional descriptive research methods remain inferior to the quantitative or qualitative research methods that allow the production of studies based on "testable observation." Traditional approaches pay attention to philosophy, history, values and law in a way that neither these quantitative nor qualitative approaches recognize as "scientific."

It is not surprising that this very same path will lead today to the so-called "revival of behaviouralism" (Hamati-Ataya, 2012, p. 19) or the "new behavioural revolution" (HafnerBurton et al., 2017, pp. S1-S3) in which contemporary behaviouralism is becoming more modest about the formulation of general theories, is becoming more aware of psychological influences on rationalization, is providing alternatives to or complementing rational choice models and is shifting its goal to the explanation of "the causes and consequences of heterogeneity across actors, including (deviation) from rationalist expectations" (HafnerBurton et al., 2017; Mintz, 2007) rather than searching for similarities. This explains the interest of contemporary behaviouralists in neuroscience and neurobiology in the study of foreign policy and diplomacy, for example (Hamati-Ataya, 2012, p. 19). Obviously, these studies have not abandoned the dream of establishing a science very similar to the natural sciences nor did they give up on the value of an empirical understanding of reality. 
Calls for a return to experimental research are on the rise because of technological and software advances that highly improve the results of this kind of research, even allowing for the emergence of new experimental approaches such as the multi-investigator experimental survey or the use of laboratory experiments to explore the impact of media, for example (Druckman et al., 2006, p. 630).

Some even advocate the "end of theories," meaning the decline in the need for explanatory models. They claim that the role of human beings in interpretation and analysis could be dispensed with. That role is now performed by the machine, which - relying on a huge amount of information; the big data - can make sound enough decisions on its own (Moawad, 2020, pp. 9-14). It is interesting to note how these calls maintain the same early behaviouralist tones of the value free science - only in a more modern language - where the role of researcher in the research process itself is reducible to that of a neutral observer, now even replaceable by an advanced computer.

Regardless of different assessments of the contemporary weight of behaviouralism, there is no doubt that behaviourialism has left a highly influential impact on the field of IR in its contemporary form. Even amongst the most informed academic circles, it still does not go without resistance to introduce studies in IR that are not based on testable observation. Cherishing the behaviouralist contribution to IR, Inanna (Hamati-Ataya, 2012, p. 20) wonders what the field would have looked like, if it had not been for behaviouralist insistence not to surrender:

[...] to the easier options of either asserting transcendental truths with no concern for their empirical accuracy or impact on human life, or of offering a loosely descriptive account of the world from an uncommon-sense, or introspective perspective.

Exactly because of this continued appreciation of a positivist understanding of the social world, the road ahead of post-positivist theories in the field of IR has not been that easy. The following section addresses some of the challenges facing post-positivist methodology and research methods in the field.

\section{Overdue confession: positivism is not the only viable scientific methodology}

The reconciliation between qualitative and quantitative research methods and the reconsideration of the possibility of formulating general theories in IR have only addressed some aspects of criticism directed at behaviouralism. In the corridors of the theory of IR, other aspects of criticism directed at behaviouralism were still lingering. Some theoretical developments would cast serious doubts about the positivist understanding of neutrality and objectivity, about the quality of the political analysis that ignores nonmaterial aspects such as ideas, values, interpretations and about the nature of political reality and its independent existence from researchers trying to understand it. It is these critical trends that would gradually draw attention to a metatheoretical relationship between neo-realism, neoliberalism and Marxism, the theoretical trilogy that Rennger [quoted in (Hamchi, 2011, p. 214)] described as variations of "the same traditional Western epistemology and its methodological correlates - rationalism, positivism and pragmatism," even though the three of them were supposed to be rivals.

By the late 1980s, calls would emerge to acknowledge an implicitly ongoing process of "(meta)theoretical restructuring of international relations theory" (Neufeld, 1995, p. 3), calls drawing attention to the emerging critical post-positivist theorizing.

"Post-positivism" is a quite ambiguous label. The term has been used at different stages of the development of the study of IR to describe different kinds of theoretical contributions. In the 1970s and 1980s, those dissatisfied with the behaviouralist obsession with a value-free 
science focusing mainly on the material aspects of the social world were sometimes referred to as post-positivists. This explains why the label "post-positivism" was granted to early contributions from the English school, social constructivism, feminism, etc. (ReusSmit, 2009a, 2009b, p. 66). Later, the label "post-positivism" will be more cautiously granted only to change seeking/reflexive/deconstructive, rather than problem-solving (Eun, 2017, pp. 593-607), contributions in the field, as a result of some growing awareness that a mere concern with values or other non-materialist aspects of the social phenomena is not a guarantee of a different mode of scientific theorizing - not a guarantee of a departure away from positivism (Hamchi, 2011; Wiener, 2004).

Actually, it makes a lot of sense to claim that many of the theories that would fall today under the critical post-positivist category have a positivist version as well. This explains one classification of theories in the field that distinguishes between positivist critical theories and post-positivist critical theories (Lamp, 2020). Feminism is different from critical feminism, and conventional or classical constructivism is different from interpretive/critical constructivism, even the critical theory itself has at least two generations (Neufeld, 1993; Neufeld, 1995).

This is partly the reason why IR literature disagrees on how to label this mainstreamcritical divide, whether to call it a third debate or a fourth debate (Diez and Steans, 2005, p. 127) to clearly distinguish it from a third debate that accepted theoretical plurality and opened up gradually not only to neo-liberal and neo-Marxist contributions but also to a feminist theory, a green theory, a constructivist theory, etc., a plurality that would, nonetheless, still be placeable under the umbrella of positivism.

\section{Post-positivism departs from a complete set of alternative assumptions}

First, theoretical reflexivity: theories are not just neutral descriptions of interactions between social actors (states, individuals, organizations, etc.). Whilst positivist theories develop hypotheses to be tested against reality (Neufeld, 1990, p. iii), post-positivist theories consider the "givens" of reality as non-given; as products of the theory itself, therefore, reality can never really become the judge of good theory (Diez and Steans, 2005, pp. 129-130).

Besides, how a researcher chooses his topics, how he selects his research methods and how he interprets or understands them is a derivative from his research preferences (Ferguson and Mansbach, 2020), from his intellectual and political interests and from the historical setting that shapes his understanding of reality, i.e. his "historical circle" (Diez and Steans, 2005, p. 139). Bias is embedded in all theories regardless of how objective or neutral they claim to be. This is why realism is usually identified in this literature as an ideology that served the goals of establishing an international system with American hegemony after the end of the Second World War (Ferguson and Mansbach, 2020). Knowledge can, therefore, only be understood within a context of time, space and interests (Krauss, 2005, p. 759).

Post-positivist theorizing warns against "self-fulfilling and self-defeating prophecies" that result from "people theorizing about the behaviour of people" (Diez and Steans, 2005, p. 141). Theories play a role in shaping the world which in turn is continuously reproduced in a way that reflects the understandings of the theories that seek to understand it. Leaders believing in realism will only see an international environment fraught with perils, they will most likely act according to a realist logic, even though they know of the existence of international cooperation or others, leading thereby to the fulfilling of realist prophecies about a world of anarchy and self-help (Krauss, 2005, p. 759).

Second, interpretivism: the post-positivist reflexive methodology conflicts with the logic of causation. It distinguishes between constitutive and causal relationships, taking pride in producing knowledge beyond what is observable, tangible, measurable and empirically testable (Diez and Steans, 2005, p. 141). No matter how similar behaviours appear to be, the
The study of international relations 
difference in the real motives and the "uninterpreted facts" behind them necessarily makes them widely different from each other (Ferguson and Mansbach, 2020). Therefore, quantitative and mathematical research tools for analysing international reality are far from sufficient, just in a way similar to the understanding of a language, where knowing the rules of grammar and the meaning of words is not enough for understanding what people say; the motives behind the words would make a true difference in meaning (Diez and Steans, 2005, p. 138).

Third, commitment to social change: post-positivist theorizing has a fundamental function of social criticism oriented toward emancipation, giving preference to change over stability and over the maintenance of the status quo by solving its problems (Chernoff, 2007, p. 131), believing in the creative role of human consciousness to guide the process of change (Neufeld, 1990, p. 3). The ability to subject one's own assumptions to self-criticism is just an innate feature of post-positivist theorizing; continuously re-evaluating their commitment to change and emancipation, reassessing the extent to which their theorizing has managed to rid itself of Eurocentric, modern and positivist biases, thereby quite often producing new versions of the same theory at every stage. Though self-criticism is usually a point of strength, it sometimes seems to impede the ability of critical post-positivist theorizing to provide some stable, accumulated theoretical structures (Abou Samra, 2016, pp. 1409-1508).

Fourth, a commitment to plurality: post-positivist theorizing will draw the attention to the irony embedded in the dedication in non-Western peripheral academic circles to a consumption of the American positivist scientific project, inspite of its shortcomings in grasping the essence of non-Western reality or representing non-Western interests (Jones, 2004).

Though post-positivist literature seriously acknowledges cultural diversity and its impact on the understanding of IR, it is important to note that the fourth debate remains a debate confined to theories competing within a secular world view. Even if the human mind is unable to explain all the aspect of political reality with reference to what is observable and empirically testable as post-positivists believe, the hidden part of the phenomenon remains produced according to them - by social interactions (Ekkehart Krippendorff, 1987, pp. 29-30). "The emancipatory reference for critical theory is immanent to practices of the society itself, rather than an external, transcendental criterion for ethical judgement" (Oliveira, 2018, p. 9). Some reflection on alternative non-secular answers to questions of IR follows in the conclusion.

\section{Post-positivism evaluated}

The evaluation of the contribution of post-positivist theories to the field is quite controversial. Critics hold them responsible for turning the field into a field of "isolated theoretical islands" with no particular subject, characterized by fluidity in the absence of a clear-cut methodology (Lamont, 2015, p. 13), turning the field into a field where anything goes (Ferguson and Mansbach, 2020). Critics accuse post-positivist theories of being unable to answer the most important questions in the field on how to explain war or how to maintain peace between states (Neufeld, 1995, pp. 330-331), even of being normative and detached from reality.

It is important to note that most of these criticisms depart basically from an inability to acknowledge the post-positivist methodology as a viable "scientific" methodology (Ferguson and Mansbach, 2020). Obviously, many of the theorists - who accepted relatively easily some plurality of research methods, failed to welcome a plurality of methodology, even less a plurality of epistemologies (Smith, 2000, p. 375).

Post-positivism, in these criticisms, seems to be judged against the dictates of a methodology that it came to revolt against. Post-positivism is not there to better provide causal explanations of reality, it is there to better change reality. 
In return, many cherish the fact that the post-positivist stage of the development of the study of IR has brought some serious novelty into the field at the level of approaches and research methods.

First, inspite of their diversity, post-positivist theories will appear to complement each other, rather than compete against each other (Diez and Steans, 2005). This is not to be confused with the neo-neo consensus, acknowledged since the 1990s, for example (Jackson and Sorenson, 2003, p. 128), where neo-liberals and neo-realists, though having much in common, will remain competing against each other. Post-positivist theories are mutually reinforcing, their approaches are reciprocated and their concerns and aspirations for changing international reality are shared. That is why compound titles such as critical feminism, feminist post-colonialism, critical constructivism and deconstructive linguistic approaches are quite familiar (Achilleos-Sarl, 2018, pp. 34-46). Concepts such as emancipation, deconstruction and the power of knowledge are well known in post-positivist literature in a way that seems better representative of real plurality, where all theories are capable of complementing each other, whilst maintaining their unique characteristics and assumptions.

Second, post-positivist theories have developed, sometimes borrowed, some unique multi-levelled research approaches.

At one level, the assumptions of post-positivist theories themselves will serve as approaches to IR. It is quite common to encounter the terms feminist approach, post-colonial approach or poststructuralist approach (Hesse-Biber and Leavy, 2006, p. 105). Here, the mere elaboration of the post-positivist critical assumptions and the mere exposure of biases, both in theory and in reality, against the excluded, the weak and the marginalized in different social contexts become a research goal in itself (Tickner, 2020, p. 628).

At a second level, some specialized research methods were developed sharing the goal of making "the voices of the voiceless heard." Here, critical post-positivist theories quite often rely on interdisciplinary approaches - approaches from the fields of philosophy, linguistics, literature, history, sociology and anthropology. These approaches are also quite often referred to as "qualitative research methods," but they differ greatly from the positivist qualitative methods previously addressed. All post-positivist qualitative approaches share the assumption that reality is not independent of those who seek to understand it, and they work on revealing biases behind common sense understandings of reality. The ethnographic approach, focusing on everyday life and global processes, dealing with experiences as diverse as life in refugee camps and online shopping (Windsor, 1989, pp. 229-270), and the discourse analytic approach, focusing on the construction of realities through political discourse (Jackson, 2007, pp. 394-426) are some telling examples of such approaches.

At a third level, "metatheoretical approaches" emerged in the field, addressing the level of the metatheory of IR; the epistemological approach, with the Afrocentric feminist epistemological approach being an example (Hesse-Biber and Leavy, 2006, pp. 80-84), the constructive engagement approach, revealing cultural similarities at the level of philosophy (Dottin, 2019, pp. 40-41), are but examples of approaches revealing biases against nonmainstream epistemologies and contemplating on power relations existing at the levels of epistemology, ontology and methodology.

Post-positivism is, therefore, credited with a gradual expansion of the field of IR, theoretical and methodological expansion, disciplinary expansion - beyond IR and political science, substantive expansion and territorial expansion beyond the West (Hellman, 2011, p. 21).

\section{Conclusion}

An overview of the development of the study of the field reveals a complex interplay between theories, methodologies, research methods and reality. It is quite difficult to say
The study of international relations 
whether the neo-realist relative failure - in the face of the end of the Cold War - caused the demise of the empiricist behaviouralist project or whether the failure of behaviouralism to grasp the aspects of the international phenomena left the neo-realist theory - and later on the neoliberal and neomarxist theories - with limited analytical resources in the face of a highly complex world in which poverty, climate change, religious resurgence, even epidemics seem to be not less dangerous to human existence than wars, free trade and the spread of capitalism - the issues of utmost priority to traditional IR theories. By the same logic it is quite difficult to say, whether the emergence of post-positivist research tools was the result of new developments in reality that were not understandable using positivist techniques, or whether the post-positivist tools have made us identify some aspects of reality to which we were completely insensible. For sure, post-positivist theorizing managed to expose some biases built into our understanding of IR; biases favouring the white, the male, the Western, the secular, the rich, the materially powerful, the rational, etc. (Grosfoguel, 2007, pp. 211-223). The interplay between reality on the one hand and theories, methods and methodologies in IR on the other hand is undeniable and quite complex.

Besides, although the narratives of the field prefer to tell the story of the triumph of realism over idealism, the triumph of behaviouralism over traditionalism and the triumph of American positivism over non-positivist alternatives, an overview of the methodological history of the field, in its first 60 years, showed that neither realism, nor behaviouralism, nor positivism have ever gone uncriticized in the field, not even in the 1960s or 1970s which used to be considered as the heydays of these scientific endeavours. In the past 40 years, these very same endeavours have been continuedly challenged in a way that further raised doubts about stories of "triumph," at least stories of absolute triumph.

One conclusion, therefore, is that the field has never really surrendered to advocates of "the single scientific methodology" discourse. Throughout its development, calls for embracing theoretical plurality, methodic plurality, methodological plurality, epistemological plurality, etc., have been a recurring feature of IR.

It makes sense to claim that the field of IR has witnessed not only methodic plurality but also methodological plurality through the stages of its development. Different research methods and different methodologies - though sometimes highly critical of each other - seem to coexist in the field of IR to this day. Years of fierce theoretical debates just led to the de facto coexistence of behaviouralist, empirical, statistical, mathematical, qualitative and quantitative research methods on the one hand and post-positivist, reflexivist, deconstructivist and interpretivist research methods on the other, reflecting methodic plurality and methodological plurality. Nothing is sacred in IR; all theories, all methods and all methodologies have undergone a process of criticism, self-criticism and change. Drawing a map of the field's methodologies and methods reveals necessarily its dynamism and its plurality.

The impact of the whole paradigmatic understanding of IR on methodologies and methods is sometimes subjected to serious criticism, because it restricts knowledge, making one unaware of a lot of things just because they fall outside the scope of concern of their adopted paradigm, hence, making researchers "method driven rather than problem driven" (Hellman, 2011).

The need to sometimes cross the strict boundaries of theoretical frameworks has been acknowledged under different labels; analytic eclecticism proposed by Sil and Katzenstein is one of them, where a degree of interdisciplinarity and a degree of complementarity between different approaches of different theoretical traditions become highly cherished (Sil and Katzenstein, 2010, p. 417).

However, the rise of new theories and the rise of new research methods have not necessarily been accompanied by the rise of new methodologies. Positivism - in its 
methodological aspects - has been underlying much of the theories of IR, even those that present themselves as rivals such as neorealism, neoliberalism, some main strands of the English school or of constructivism.

More importantly, positivism - in its aspects as a secular theory to existence - remains the dominant underlying view of positivist and post-positivist theorizing in IR.

This paper has basically reflected on the interplay between methodology and methods as manifest in the Western course of development of IR theory. An emerging non-Western research course has been deliberately left out for future research. An "Islamic Civilizational Paradigm of IR" would clearly distinguish itself from positivism and post-positivism, calling, thereby, upon a methodology that combines reason and revelation and research methods that comfortably accept this duality (Mostafa, 2016; Abou Samra, 2019). Attempts at developing a Chinese theory of IR - though strongly benefitting from a constructivist turn - would suggest the importance of making use of Chinese philosophical heritage (Noesselt, 2012). A Chinese theory and an Islamic paradigm are just but examples of many emerging non-Western alternative theoretical understandings of IR reflecting cultural particularity. These reflections even furtherly suggest that a plurality of methodologies and methods can go far beyond the positivist and post-positivist understandings of a world making one wonder how different IR in the age of a truly "global IR" can look like (Acharya and Buzan, 2017, p. 7), a stage opening up slowly and somewhat hesitantly to diverse understandings of reality, history, life and existence from around the world.

\section{References}

Abou Samra, A. (2016), "The concept of universalism in international relations: a comparative study of critical theories (Mafhoum Alalameya Fee Alelaqat Aldawleyah: Derasah fee Etegahat Naqdeyah Muqaranah)", in Mostafa, N.M. (Ed.), International Relations in a Changing World: Comparative Paradigms and Approaches (Alelaqat Adawleyah Fee Alam Mutaghayer: Manthourat we Madakhel Muqaranah), The Civilization Centre for Studies and Researches, Cairo, pp. 1409-1508.

Abou Samra, A. (2019), "An Islamic paradigm in a new map of the field of IR (Manthour Hadari Islami Fee Khareetah Gadeedah Lehaql Alelaqat Aldawleyah)", The Journal of the Faculty of Economics and Political Science (Magalet Kolleyat Aliqtesad wa Aloloum Alseyaseyah), Vol. 20 №. 3.

Abul-Fadl, M.M. (1994), "Contemporary social theory: Tawhidi projections", The American Journal of Islamic Social Sciences, Vol. 11 No. 3.

Acharya, A. and Buzan, B. (2017), "Why is there no non-Western IR theory? Ten years on", International Relations of the Asia-Pacific, Vol. 17 No. 3.

Achilleos-Sarl, C. (2018), "Reconceptualising foreign policy as gendered, sexualised and racialised: towards a postcolonial feminist foreign policy (analysis)", Journal of International Women's Studies, Vol. 19 No. 1.

Badran, W. (2000), The Study of International Relations in Western Literature and the Project of International Relations in Islam (Derasat Alelaqat Aldawleyah Fee Aladabeyat Algharbeyah we Mashrou Alelaqat Aldawleyah fe Alislam)), The Center for Political Research and Studies, Faculty of Economics and Political Science, Cairo University, Cairo, pp. 69-96.

Boassen, C. (1991), "Approaches to the study of international relations", In Search of Peace Research: Essays by Charles Boassen, Macmillan Academic and Professional, London.

Chernoff, F. (2007), Theory and Metatheory in International Relations: Concepts and Contending Accounts, Palgrave Macmillan, New York, NY.

Davis, R.G. (1965), “A study of some behavioural approaches to international relations”, Master Thesis, Political Science Department, The University of Wyoming. 
Diez, T. and Steans, J. (2005), "A useful dialogue? Habermas and international relations", Review of International Studies, Vol. 31 No. 1.

Dolan, L.M. (2014), "Three pluralisms: theories, methodologies, and levels of analysis in the study of world politics", Departmental Honors Projects 27, available at: https://digitalcommons.hamline.edu/dhp/27

Dottin, P.A. (2019), "Sino-African philosophy: a re-constructive engagement", Comparative Philosophy, Vol. 10 No. 1.

Druckman, J.N., Green, D.P., Kuklinski, J.H. and Lupia, A. (2006), "The growth and development of experimental research in political science", American Political Science Review, Vol. 100 No. 04.

Dyer, H.C. and Mangasarian, L. (1989), "Editors' introduction", in Dyer, H.C. and Mangasarian, L. (Eds), The Study of International Relations: The State of the Art, Palgrave Macmillan in Association with Millenium Journal of International Studies, London.

Ekkehart Krippendorff, E. (1987), "The dominance of American approaches in international relations", Millennium: Journal of International Studies, Vol. 16, No. 2, pp. 207-214.

El-Hayagna, A.M.H. (2001), "Level of analysis and research methods in the Arabic studies of international relations. Analytical study: 1966-1995”, Studies: Humanities and Social Sciences, Vol. 28.

Eun, Y.-S. (2017), “To what extent is post-positivism 'practised' in international relations? Evidence from China and the USA", International Political Science Review, Vol. 38 No. 5.

Ferguson, Y. and Mansbach, R. (2020), 'Reflections on the 'third debate', the 'third debate' 25 years later, symposium, International Studies Association", available at: www.isanet.org/Publications/ISQ/Posts/ID/ 304/25-Years-after-The-Third-Debate-Two-pianissimo-bravos-for-IR-Theory (accessed 2019)

Ferguson, Y.H. and Mansbach, R.W. (1988), "The elusive quest: theory and international politics", International Affairs, Vol. 64 No. 4, Autumn.

Finnegan, R. (1972), "International relations: the disputed search for method", The Review of Politics, Vol. 34 No. 1.

Forward, N. (1971), The Field of Nations: An Account of Some New Approaches to International Relations, Palgrave Macmillan, London and Basingstoke.

Grigsby, E. (2011), Analyzing Politics: An Introduction to Political Science, Cengage Learning.

Grosfoguel, R. (2007), "The epistemic decolonial turn: beyond political-economy paradigms", Cultural Studies, Vol. 21 Nos $2 / 3$.

Hafner-Burton, E.M., Haggard, S. and Lake, D.A. (2017), "The behavioral revolution and international relations", International Organization, Vol. 71.

Hamati-Ataya, I. (2012), "Behavioralism", Oxford University Press, available at: www.academia.edu/ 593814/Behavioralism_in_Oxford_Research_Encyclopedia_of_International_Studies_OUP_ed. _Ren\%C3\%A9e_Marlin-Bennett_2019_2012_

Hamchi, M. (2011), "IR fourth debate: pluralistic or hegemonic? Limitations to bridging the gap", Algerian Review of Security and Development, Vol. 1.

Hay, C. (2006), "Political Ontology", in Goodin, R.E. and Tilly, C. (Eds), The Oxford Handbook of Contextual Political Analysis, available at: https:/www.oxfordhandbooks.com/

Hellman, G. (2011), "International relations as a field of study", in Badie, B., Berg-Schlosser, D. and Morlino, L. (Eds), International Encyclopedia of Political Science, Sage Publication (The online version in abridged form is available at: www.sage-reference.com/view/intlpoliticalscience/n295.xml).

Herakovic, J.M. (1983), "The cultural roots of behaviourism”, Master's Thesis, Department of Psychology, The Graduate College, Western Michigan University.

Hesse-Biber, S.N. and Leavy, P. (2006), The Practice of Qualitative Research, Sage Publications, London and New Delhi.

Hoffman, M. (1989), "Critical theory and the inter-paradigm debate", in Dyer, H.C. and Mangasarian, L. (Eds), The Study of International Relations: The State of the Art, Palgrave Macmillan in Association with Millennium Journal of International Studies, London. 
Jackson, R. (2007), “Constructing enemies: 'Islamic terrorism' in political and academic discourse", Government and Opposition, Vol. 42 No. 3.

Jackson, R. and Sorenson, J. (2003), Introduction to International Relations: Theories and Approaches, Second ed. Oxford University Press, Oxford.

Jones, B.G. (2004), "From Eurocentrism to epistemological internationalism: power, knowledge and objectivity in international relations", Cambridge, Theorizing Ontology, Annual Conference of the International Association for Critical Realism, University of Cambridge.

Kanfo, S. (2017), "A methodological turn long overdue, or why it is time for critical scholars to cut their losses”, in Dyvik, S.L., Selby, J. and Wilkinson, R. (Eds), What's the Point of International Relations, Routledge, London.

Kaplan, A. (1964), The Conduct of Inquiry: Methodology for Behavioral Science, Chandler Publishing Co, Scranton.

Krauss, S.E. (2005), "Research paradigms and meaning making: a primer", The Qualitative Report, Vol. 10 No. 4.

Lacatus, C., Schade, D. and Yao, Y. (2015), "Quo Vadis IR: method, methodology and innovation", Millennium: Journal of International Studies, Vol. 43 No. 3.

Lamont, C. (2015), Research Method in International Relations, Sage Publications, London.

Lamp, N. (2020), "Towards a critical theory of globalization", San Diego, 47th Annual Convention of the International Studies Association (www.allacademic.com).

Linklater, A. (1986), "Realism, Marxism and critical international theory", Review of International Studies, Vol. 12 No. 4.

Little, R. (1991), "International relations and the methological turn”, Political Studies, Vol. 39 No. 3, pp. 463-478.

McCalla, R.B. (1996), "NATO's persistence after the cold war", International Organization, Vol. 50 No. 3.

Mahoney, J. and Goertz, G. (2006), "A tale of two cultures: contrasting quantitative and qualitative research", Political Analysis, Vol. 14 No. 3.

Mintz, A. (2007), "Behavioral IR as a subfield of international relations”, International Studies Review, Vol. 9 No. 1.

Moawad, A. (2020), "The effect of big data on the theories of international relations (Ta'theer Albayanat Aldakhmah fee Nathareyat Al'elaqat Aldawleyah)", International Politics (Alseyasah Aldawleyah) Supplement, Vol. 219 No. 2020.

Mosafa, N. (2010), "The problematics of research and teaching in IR from a comparative civilizational perspective (Eshkaleyat Albahth wa Altadrees fee Elm Alelaqat Aldawleyah men Manthour Hadari Muqaran)", The Islamic Methodology (Almanhageyah Alislameyah), The International Institute for Islamic Thought, Cairo, pp. 840-846.

Mostafa, N.M. (2016), "The development of IR science between the great debates and the dialectics of epistemics (Masar Elm Alelaqat Aldawleyah bayna Gedal Almanthourat Alkobra wa Ekhtelaf Alnamatheg Ama'refeyah)", in Mostafa, N. (Ed.), International Relations in a Changing World: Comparative Paradigms and Approaches (Alelaqat Aldawleyah fee Alam Mutaghayer: Manthourat we Madakhel Muqaranah), The Civilization Centre for Studies and Researches, Cairo, pp. 57-70.

Neufeld, M.A. (1990), "Toward a restructuring of international relations theory", PhD Thesis, The Faculty of Graduate Studies and Research, Carleton University.

Neufeld, M.A. (1993), "Interpretation and the 'science' of international relations", Review of International Studies, Vol. 19 No. 1.

Neufeld, M.A. (1995), Toward a Restructuring of International Relations Theory, Cambridge University Press, Cambridge.

Noesselt, N. (2012), Is There a “Chinese School” of IR?, German Institute of Global and Area Studies.

Oliveira, G.C. (2018), "Reconstructive methodology and critical international relations theory", Contexto Internacional, Vol. 40 No. 1.
The study of international relations 
Reus-Smit, C. (2009a), "Constructivism and the English school", in Navari, C. (Ed.), Theorising International Society: English School Methods, Palgrave Macmillan, London.

Reus-Smit, C. (2009b), "On the distinction between positivist and post-positivist versions", in Navari, C. (Ed.), Theorising International Society: English School Methods, Palgrave Macmillan, London.

Sil, R. and Katzenstein, P.J. (2010), "Analytic eclecticism in the study of world politics: reconfiguring problems and mechanisms across research traditions", Perspectives on Politics, Vol. 8 No. 2, pp. 411-431.

Smith, S. (1989), "Paradigm dominance in international relations as a social science", in Dyer, H.C. and Mangasarian, L. (Eds), The Study of International Relations: The State of the Art, Palgrave Macmillan in association with Millenium Journal of International Studies.

Smith, S. (2000), "The discipline if international relations: still and American social science?", British Journal of Politics and International Relations, Vol. 2 No. 3.

Sprinz, D.F. and Wolinsky-Nahmias, Y. (2004), "Introduction: methodology in international relations research", in Sprinz, D.F. and Wolinsky-Nahmias, Y. (Eds), Models, Numbers and Cases: Methods for Studying International Relations, The University of MI Press.

Tickner, A. (2020), "Core, periphery and (neo)imperialist international relations”, European Journal of International Relations, Vol. 19 No. 3.

Waltz, K. (1979), Theory of International Politics, Addison Wesley, London.

Wiener, A. (2004), "Contested compliance: interventions on the normative structure of world politics", European Journal of International Relations, Vol. 10 No. 2, p. 191.

Windsor, P. (1989), "Foreward”, in Dyer, H.C. and Mangasarian, L. (Eds), The Study of International Relations: The State of the Art, Palgrave Macmillan in Association with Millennium Journal of International Studies, London.

\section{Further readings}

Akinyoade, D. (2012), "Ontology and epistemology for peace and conflict studies", International Conference on the Security Sector and Conflict Management in Nigeria (University of Ibadan, Nigeria), 14-16 August.

George, S. (1976), "The reconciliation of the 'classical' and 'scientific' approaches to international relations", Millennium Joumal of Scientific Studies, available at: https:/journals.sagepub.com/doi/pdf/10.1177/ 03058298760050010301

Lapid, Y. (1989), "The third debate: on the prospects of international theory in a post-positivist era", International Studies Quarterly, Vol. 33 No. 3.

Lapid, Y. (2020), "25 years after the third debate: two (pianissimo) bravos for IR theory, the "third debate' 25 years later symposium", available at: www.isanet.org/Publications/ISQ/Posts/ID/304/ 25-Years-after-The-Third-Debate-Two-pianissimo-bravos-for-IR-Theory (accessed 2019).

\section{Corresponding author}

Amira Abou Samra can be contacted at: amiraabousamra@feps.edu.eg

For instructions on how to order reprints of this article, please visit our website: 